\title{
Synthesis of fragrance compounds from acyclic monoterpenes: Rhodium catalyzed hydroformylation and tandem hydroformylation/acetalization of linalool and $\beta$-citronellene
}

\author{
Camila G. Vieira, Eduardo N. dos Santos, Elena V. Gusevskaya* \\ Departamento de Química, Universidade Federal de Minas Gerais, 31270-901 Belo Horizonte, MG, Brazil
}

\section{A R T I C L E I N F O}

\section{Article history:}

Received 21 February 2013

Received in revised form 21 June 2013

Accepted 25 June 2013

Available online 4 July 2013

\section{Keywords:}

Acetalization

Citronellene

Hydroformylation

Linalool

Monoterpenes

Rhodium

\begin{abstract}
A B S T R A C T
Rhodium-catalyzed hydroformylation of acyclic monoterpenic compounds, i.e., linalool and $\beta$ citronellene, was studied in toluene and ethanol solutions in the presence of $\mathrm{PPh}_{3}$ or $\mathrm{P}\left(\mathrm{O}-\mathrm{O}_{-}{ }^{\mathrm{t}} \mathrm{BuPh}\right)_{3}$ ligands. Although both substrates have a monosubstituted terminal double bond, they show different behavior under the hydroformylation conditions. In toluene, linalool gave almost quantitatively a cyclic hemiacetal; whereas the hydroformylation of $\beta$-citronellene resulted in two isomeric aldehydes also in a nearly quantitative combined yield. The reactions occurred approximately two times faster in ethanol than in toluene giving the corresponding acetals even in the absence of additional acid co-catalysts. In the absence of phosphorous ligands, linalool (differently from $\beta$-citronellene) was very resistant to hydroformylation probably due to the binding with rhodium through both the double bond and the hydroxyl group to form stable chelates. The $\mathrm{P}\left(\mathrm{O}-\mathrm{O}^{-}{ }^{\mathrm{t}} \mathrm{BuPh}\right)_{3}$ ligand exerted a remarkable effect on the reactivity of both substrates accelerating the reactions by 5-20 times as compared to the system with $\mathrm{PPh}_{3}$. Several fragrance compounds were obtained in high yields through a simple one-pot procedure starting from the substrates easily available from natural bio-renewable resources.
\end{abstract}

(c) 2013 Elsevier B.V. All rights reserved.

\section{Introduction}

Terpenic compounds, in general, are an important biomassbased renewable feedstock for the industrial production of fragrances, perfumes, flavors and pharmaceuticals as well as synthetic intermediates [1-4]. These natural compounds are easily available from essential oils of many plants and flowers. For several years, we have been interested in catalytic transformations of terpenes to more valuable chemicals, in particular, via hydroformylation reactions [5-9]. Rhodium or cobalt catalyzed hydroformylation is an industrially important tool for the synthesis of oxygen-containing compounds from alkenes [10]. The process is usually performed in aprotic solvents and gives aldehydes as main products, which can be further converted to other desired compounds.

Although the hydroformylation of more abundant monoterpenes, such as limonene, $\beta$-pinene, myrcene and camphene, was quite extensively studied [11-20], only few reports appeared on the hydroformylation of linalool [11,21-23] and $\beta$-citronellene (dihydromyrcene) [11,24,25]. Linalool, a monoterpenoid allylic alcohol with a pleasant lily odor, is a key building block for the

\footnotetext{
* Corresponding author. Tel.: +55 31 34095741; fax: +55 3134095700 .

E-mail address: elena@ufmg.br (E.V. Gusevskaya).
}

synthesis of various vitamins and fragrances, such as vitamin A, vitamin E, citral and citronellol $[3,4]$. Linalool is found in essential oils of several plants, e.g., Brazilian rosewood and Chinese Ho leaf oils, but most linalool is produced synthetically from $\alpha$ pinene, a cheap major constituent of turpentine oils obtained from coniferous trees $[3,4,26]$. The hydroformylation of allylic alcohols represents a direct method for the synthesis of substituted tetrahydrofurans since primarily formed hydroxyl-aldehydes undergo a spontaneous intramolecular cyclization to give five-membered hemiacetals [13,27-30]. Hemiacetals can be further converted in other useful products: acetals, lactones or dihydrofuran derivatives.

$\beta$-Citronellene is also a valuable feedstock for the industrial synthesis of various fragrance ingredients, e.g., dihydromyrcenol and cyclodemol [3]. $\beta$-Citronellene is commercially produced by the thermal isomerization of pinane obtained through the hydrogenation of $\alpha$-pinene [3,31,32]. $\alpha$-Pinene is one of the most widespread monoterpene hydrocarbons; its content in turpentine oils can reach $85 \%$. Aldehydes and acetals resulting from the hydroformylation of $\beta$-citronellene and linolool are valuable fragrance compounds with fresh floral and/or green citrus odors [11].

Following a general trend in synthetic organic chemistry, we have recently directed our efforts to involve the hydroformylation reaction in tandem reaction sequences $[8,9,33,34]$. Such catalytic processes can lead directly from alkenes to various important products through a simple one-pot procedure without the isolation of 
aldehydes. In particular, we integrated the hydroformylation and aldehyde acetalization steps in one reactor by performing the process in ethanol solutions, which allowed to obtain diethyl acetals from various monoterpenes [9,35].

In continuation of our ongoing project on valorization of natural ingredients of essential oils, we report herein the rhodiumcatalyzed hydroformylation of linalool (1a) and $\beta$-citronellene (2a) as well as the tandem hydroformylation/acetalization of these substrates under mild non-acidic conditions. All isolated products (aldehydes, hemiacetals and acetals) have a pleasant scent and can be useful as components of synthetic fragrances.

\section{Experimental}

All chemicals were purchased from commercial sources and used as received, unless otherwise indicated. Racemic linalool [ $( \pm)-$ 3,7-dimethyl-1,6-octadien-3-ol] and (-)- $\beta$-citronellene [dihydromyrcene, (R)-(-)-3,7-dimethyl-1,6-octadiene] acquired from Aldrich were used as substrates. $[\mathrm{Rh}(\mathrm{COD})(\mathrm{OMe})]_{2}(\mathrm{COD}=1,5-$ cyclooctadiene) was prepared by a published method [36]. Tris $\left(\mathrm{O}^{\mathrm{t}}\right.$ butylphenyl $)$ phosphite, $\mathrm{P}\left(\mathrm{O}-\mathrm{o}^{\mathrm{t}}{ }^{\mathrm{BuPh}}\right)_{3}$, was prepared as described in [37] and purified by column chromatography (silica gel 60) using mixture of hexane and $\mathrm{CHCl}_{3}$ as eluents. Toluene was purified under reflux with sodium wire-benzophenone for $8 \mathrm{~h}$ and then distilled under argon Ethanol was purified under reflux with magnesium turnings and iodine crystals for $6 \mathrm{~h}$ and then distilled under argon.

Catalytic experiments were carried out in homemade stainless steal reactors with magnetic stirring. Reactions were followed by gas chromatography (GC) by sampling the liquid phases through a valved dip tube. The products were analyzed by gas chromatography (GC-Shimadzu QP2010, Rtx ${ }^{\circledR}-5$ MS capillary column, FID detector). Conversion and selectivity were determined by GC. The GC mass balance was based on the substrate charged using dodecane as an internal standard. Initial turnover frequencies (TOFs) were measured at low conversions (up to 20-40\%) taking aliquots at short reaction times for GC analysis.

In a typical run, toluene or ethanol $(20.0 \mathrm{~mL})$ containing $[\mathrm{Rh}(\mathrm{COD})(\mathrm{OMe})]_{2} \quad(5.0-6.0 \mu \mathrm{mol})$, phosphorus ligand $(0-0.6 \mathrm{mmol})$, substrate $(2-6 \mathrm{mmol})$, and dodecane $(1-3 \mathrm{mmol}$, internal standard) was transferred under argon into a stainless steel autoclave, which was pressurized to $20-80 \mathrm{~atm}\left(\mathrm{CO} / \mathrm{H}_{2}=1 / 2\right.$ to $2 / 1$ ), placed in an oil bath $\left(40-80^{\circ} \mathrm{C}\right)$, and magnetically stirred. After the reaction was carried out and cooled to room temperature, the excess $\mathrm{CO}$ and $\mathrm{H}_{2}$ were slowly vented.

The products were separated by column chromatography (silica gel 60) using mixtures of hexane and $\mathrm{CH}_{2} \mathrm{Cl}_{2}$ as eluents and identified by GC-MS, ${ }^{1} \mathrm{H}$, and ${ }^{13} \mathrm{C}$ NMR. The assignment of ${ }^{1} \mathrm{H}$ and ${ }^{13} \mathrm{C}$ NMR signals was made using bidimensional techniques. NMR spectra were recorded in $\mathrm{CDCl}_{3}$ using a Bruker $400 \mathrm{MHz}$ spectrometer, with TMS as an internal standard. Mass spectra were obtained on a Shimadzu QP2010-PLUS instrument operating at $70 \mathrm{eV}$.

For the NMR and MS data cis-5-methyl-5-(4-methyl-3pentenyl)tetrahydro-2-furanol (1c cis and trans) see [23].

Data for 4,8-dimethyl-7(8)-nonenal (2b): MS (70 eV, EI): $m / z(\%)$ :

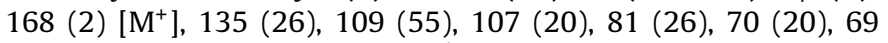
(100), 67 (27), 56 (21), 55 (45). ${ }^{1} \mathrm{H}$ NMR (400 MHz, $\mathrm{CDCl}_{3}, 25^{\circ} \mathrm{C}$, TMS): $\delta=0.89\left(\mathrm{~d},{ }^{3} \mathrm{~J}=6.4 \mathrm{~Hz}, 3 \mathrm{H} ; \mathrm{C}^{10} \mathrm{H}_{3}\right), 1.12-1.22\left(\mathrm{~m}, 1 \mathrm{H} ; \mathrm{C}^{4} \mathrm{HH}\right)$, $1.28-1.38\left(\mathrm{~m}, 1 \mathrm{H} ; \mathrm{C}^{4} \mathrm{HH}\right), 1.40-1.50\left(\mathrm{~m}, 2 \mathrm{H} ; \mathrm{C}^{3} \mathrm{H}\right.$ and $\left.\mathrm{C}^{2} \mathrm{HH}\right), 1.60(\mathrm{~s}$, $\left.3 \mathrm{H} ; \mathrm{C}^{8} \mathrm{H}_{3}\right), 1.68$ (s, 3H; $\left.\mathrm{C}^{9} \mathrm{H}_{3}\right), 1.65-1.75\left(\mathrm{~m}, 1 \mathrm{H} ; \mathrm{C}^{2} \mathrm{HH}\right), 1.90-2.05$ $\left(\mathrm{m}, 2 \mathrm{H} ; \mathrm{C}^{5} \mathrm{H}_{2}\right), 2.38-2.48\left(\mathrm{~m}, 2 \mathrm{H} ; \mathrm{C}^{1} \mathrm{H}_{2}\right), 5.09\left(\mathrm{t},{ }^{3} \mathrm{~J}=7.0 \mathrm{~Hz}, 1 \mathrm{H}\right.$; $\left.\mathrm{C}^{6} \mathrm{H}\right), 9.77 \mathrm{ppm}\left(\mathrm{t},{ }^{3} \mathrm{~J}=1.8 \mathrm{~Hz}, 1 \mathrm{H}\right.$; CHO $) .{ }^{13} \mathrm{C} \mathrm{NMR}\left(100 \mathrm{MHz}, \mathrm{CDCl}_{3}\right.$, $\left.25^{\circ} \mathrm{C}, \mathrm{TMS}\right): \delta_{\mathrm{C}}=17.61\left(C^{8}\right), 19.21\left(C^{10}\right), 25.41\left(C^{5}\right), 25.67\left(C^{9}\right), 28.83$ $\left(C^{2}\right), 32.00\left(C^{3}\right), 36.73\left(C^{4}\right), 41.66\left(C^{1}\right), 124.51\left(C^{6}\right), 131.37\left(C^{7}\right)$, $202.89 \mathrm{ppm}$ (CHO).
Data for 2,3,7-trimethyl-6(7)-octenal (2c, a mixture of two diastereoisomers: (2R,3R) and (2S,3R), shorter GC retention time compared to 2b): MS (70 eV, EI): $m / z$ (\%): 168 (2) [ $\left.\mathrm{M}^{+}\right], 135$ (19), 109 (43), 95 (76), 85 (21), 83 (34), 82 (32), 70 (25), 69 (100), 67 (43), 56 (26), 55 (57). ${ }^{1} \mathrm{H}$ NMR ( $\left.400 \mathrm{MHz}, \mathrm{CDCl}_{3}, 25^{\circ} \mathrm{C}, \mathrm{TMS}\right): \delta=0.83$ and $0.98\left(\mathrm{~d},{ }^{3} \mathrm{~J}=7.0 \mathrm{~Hz}, 3 \mathrm{H} ; \mathrm{C}^{1} \mathrm{H}_{3}\right), 0.89\left(\mathrm{~d},{ }^{3} \mathrm{~J}=6.4 \mathrm{~Hz}, 3 \mathrm{H} ; \mathrm{C}^{10} \mathrm{H}_{3}\right)$, $1.12-1.22\left(\mathrm{~m}, 1 \mathrm{H} ; \mathrm{C}^{4} \mathrm{HH}\right), 1.28-1.38\left(\mathrm{~m}, 1 \mathrm{H} ; \mathrm{C}^{4} \mathrm{HH}\right), 1.40-1.50(\mathrm{~m}$, $\left.2 \mathrm{H} ; \mathrm{C}^{3} \mathrm{H}\right), 1.60\left(\mathrm{~s}, 3 \mathrm{H} ; \mathrm{C}^{8} \mathrm{H}_{3}\right), 1.68\left(\mathrm{~s}, 3 \mathrm{H} ; \mathrm{C}^{9} \mathrm{H}_{3}\right), 1.90-2.05(\mathrm{~m}, 2 \mathrm{H}$; $\left.\mathrm{C}^{5} \mathrm{H}_{2}\right), 2.25-2.35\left(\mathrm{~m}, 1 \mathrm{H} ; \mathrm{C}^{2} \mathrm{H}\right), 5.09\left(\mathrm{t},{ }^{3} \mathrm{~J}=7.0 \mathrm{~Hz}, 1 \mathrm{H} ; \mathrm{C}^{6} \mathrm{H}\right), 9.68$ and $9.67 \mathrm{ppm}$ (br. s, $1 \mathrm{H}$; CHO). ${ }^{13} \mathrm{C}$ NMR $\left(100 \mathrm{MHz}, \mathrm{CDCl}_{3}, 25^{\circ} \mathrm{C}, \mathrm{TMS}\right)$ : $\delta_{\mathrm{C}}=14.07$ and $15.34\left(C^{1}\right), 17.27\left(C^{8}\right), 19.20\left(C^{10}\right), 25.63\left(C^{5}\right), 25.67$ $\left(C^{9}\right), 32.15$ and $33.40\left(C^{3}\right), 33.25$ and $34.74\left(C^{4}\right), 50.51$ and 51.50 $\left(C^{2}\right), 123.98$ and $124.06\left(C^{6}\right), 131.78$ and $131.80\left(C^{7}\right), 205.64$ and $205.70 \mathrm{ppm}$ (CHO).

Data for (cis) (1d cis): MS (70 eV, EI): $m / z(\%)$ : (2.5) [ $\left.\mathrm{M}^{+}\right], 166$ (15) [ $\left.\mathrm{M}^{+}-\mathrm{C}_{2} \mathrm{H}_{5} \mathrm{OH}\right], 129$ (79), 123 (20), 122 (54), 109 (26), 108 (12), 107 (55), 101 (39), 95 (25), 86 (27), 85 (22), 83 (56), 69 (100), 67 (20), 58 (22), 55 (35). ${ }^{1} \mathrm{H}$ NMR $(400 \mathrm{MHz}$, $\left.\mathrm{CDCl}_{3}, 25^{\circ} \mathrm{C}, \mathrm{TMS}\right): \delta=1.15-1.25\left(\mathrm{~m}, 3 \mathrm{H} ; \mathrm{CH}_{2} \mathrm{CH}_{3}\right), 1.33(\mathrm{~s}, 3 \mathrm{H}$; $\left.\mathrm{C}^{10} \mathrm{H}_{3}\right), 1.40-1.50\left(\mathrm{~m}, 2 \mathrm{H} ; \mathrm{C}^{4} \mathrm{H}_{2}\right), 1.61\left(\mathrm{~s}, 3 \mathrm{H} ; \mathrm{C}^{8} \mathrm{H}_{3}\right), 1.67(\mathrm{~s}, 3 \mathrm{H}$; $\left.\mathrm{C}^{9} \mathrm{H}_{3}\right), 1.75-1.90\left(\mathrm{~m}, 2 \mathrm{H} ; \mathrm{C}^{2} \mathrm{H}_{2}\right), 1.90-2.00\left(\mathrm{~m}, 4 \mathrm{H} ; \mathrm{C}^{5} \mathrm{H}_{2}\right.$ and $\left.\mathrm{C}^{1} \mathrm{H}_{2}\right), 3.35-3.45\left(\mathrm{~m}, 1 \mathrm{H} ; \mathrm{CHHCH}_{3}\right), 3.70-3.80\left(\mathrm{~m}, 1 \mathrm{H} ; \mathrm{CHHCH}_{3}\right)$, 5.05-5.15 ppm (m, 2H; $\mathrm{C}^{6} \mathrm{H}$ and $\left.\mathrm{OCHOC}_{2} \mathrm{H}_{5}\right) .{ }^{13} \mathrm{C}$ NMR $(100 \mathrm{MHz}$, $\left.\mathrm{CDCl}_{3}, 25^{\circ} \mathrm{C}, \mathrm{TMS}\right): \delta_{\mathrm{C}}=15.21\left(\mathrm{CH}_{2} \mathrm{CH}_{3}\right), 17.55\left(\mathrm{C}^{8}\right), 23.23\left(\mathrm{C}^{5}\right)$, $25.42\left(C^{9}\right), 28.24\left(C^{10}\right), 33.29\left(C^{1}\right), 34.36\left(C^{2}\right), 41.91\left(C^{4}\right), 61.99$ $\left(\mathrm{CH}_{2} \mathrm{CH}_{3}\right), 84.17\left(C^{3}\right), 103.83\left(\mathrm{OCHOC}_{2} \mathrm{H}_{5}\right), 124.45\left(C^{6}\right), 131.27 \mathrm{ppm}$ $\left(C^{7}\right)$.

Data for trans-5-ethoxy-2-methyl-2-(4-methyl-3pentenyl)tetrahydrofuran (1d trans, shorter GC retention time compared to 1d cis): MS (70 eV, EI): $m / z(\%): 212(0.2)\left[\mathrm{M}^{+}\right], 166$ (23) $\left[\mathrm{M}^{+}-\mathrm{C}_{2} \mathrm{H}_{5} \mathrm{OH}\right], 129$ (73), 123 (27), 122 (80), 109 (32), 108 (20), 107 (84), 101 (37), 95 (27), 86 (22), 85 (21), 83 (57), 69 (100), 67 (25), 58 (20), 55 (38). ${ }^{1} \mathrm{H}$ NMR ( $\left.400 \mathrm{MHz}, \mathrm{CDCl}_{3}, 25^{\circ} \mathrm{C}, \mathrm{TMS}\right)$ : $\delta=1.15-1.25\left(\mathrm{~m}, 3 \mathrm{H} ; \mathrm{CH}_{2} \mathrm{CH}_{3}\right), 1.33\left(\mathrm{~s}, 3 \mathrm{H} ; \mathrm{C}^{10} \mathrm{H}_{3}\right), 1.62(\mathrm{~s}, 3 \mathrm{H}$; $\left.\mathrm{C}^{8} \mathrm{H}_{3}\right), 1.67\left(\mathrm{~s}, 3 \mathrm{H} ; \mathrm{C}^{9} \mathrm{H}_{3}\right), 1.65-1.70\left(\mathrm{~m}, 2 \mathrm{H} ; \mathrm{C}^{4} \mathrm{H}_{2}\right), 1.90-2.00(\mathrm{~m}$, $6 \mathrm{H} ; \mathrm{C}^{2} \mathrm{H}_{2}, \mathrm{C}^{5} \mathrm{H}_{2}$ and $\left.\mathrm{C}^{1} \mathrm{H}_{2}\right), 3.35-3.45\left(\mathrm{~m}, 1 \mathrm{H} ; \mathrm{CHHCH}_{3}\right), 3.70-3.80$ (m, $\left.1 \mathrm{H} ; \mathrm{CHHCH}_{3}\right), 5.05-5.15 \mathrm{ppm}\left(\mathrm{m}, 2 \mathrm{H} ; \mathrm{C}^{6} \mathrm{H}\right.$ and $\left.\mathrm{OCHOC}_{2} \mathrm{H}_{5}\right)$. ${ }^{13} \mathrm{C}$ NMR $\left(100 \mathrm{MHz}, \mathrm{CDCl}_{3}, 25^{\circ} \mathrm{C}, \mathrm{TMS}\right): \delta_{\mathrm{C}}=15.13\left(\mathrm{CH}_{2} \mathrm{CH}_{3}\right), 17.49$ $\left(C^{8}\right), 23.57\left(C^{5}\right), 26.07\left(C^{9}\right), 28.24\left(C^{10}\right), 32.69\left(C^{1}\right), 34.77\left(C^{2}\right), 42.78$ $\left(C^{4}\right), 62.10\left(\mathrm{CH}_{2} \mathrm{CH}_{3}\right), 84.45\left(C^{3}\right), 103.57\left(\mathrm{OCHOC}_{2} \mathrm{H}_{5}\right), 124.65\left(C^{6}\right)$, $131.10 \mathrm{ppm}\left(C^{7}\right)$.

Data for 9,9-diethoxy-2,6-dimethylnon-2-ene(2d): MS (70 eV, EI): $m / z(\%): 196$ (6) [ $\left.\mathrm{M}^{+}-\mathrm{C}_{2} \mathrm{H}_{5} \mathrm{OH}\right], 135$ (20), 109 (29), 107 (22), 103 (100), 97 (20), 96 (29), 95 (51), 85 (28), 81 (41), 75 (84), 69 (55), 57 (31). ${ }^{1} \mathrm{H}$ NMR $\left(400 \mathrm{MHz}, \mathrm{CDCl}_{3}, 25^{\circ} \mathrm{C}\right.$, TMS $): \delta=0.85\left(\mathrm{~d},{ }^{3} \mathrm{~J}=6.4 \mathrm{~Hz}\right.$, $\left.3 \mathrm{H} ; \mathrm{C}^{10} \mathrm{H}_{3}\right), 1.18\left(\mathrm{t},{ }^{3} \mathrm{~J}=6.8 \mathrm{~Hz}, 6 \mathrm{H} ; \mathrm{CH}_{2} \mathrm{CH}_{3}\right), 1.10-1.20\left(\mathrm{~m}, 2 \mathrm{H} ; \mathrm{C}^{4} \mathrm{HH}\right.$ and $\left.\mathrm{C}^{2} \mathrm{HH}\right), 1.25-1.45\left(\mathrm{~m}, 3 \mathrm{H} ; \mathrm{C}^{4} \mathrm{HH}, \mathrm{C}^{2} \mathrm{HH}\right.$ and $\left.\mathrm{C}^{3} \mathrm{H}\right), 1.57(\mathrm{~s}, 3 \mathrm{H}$; $\left.\mathrm{C}^{8} \mathrm{H}_{3}\right), 1.50-1.65$ (m, 2H; $\left.\mathrm{C}^{1} \mathrm{H}_{2}\right), 1.65$ (s, 3H; $\left.\mathrm{C}^{9} \mathrm{H}_{3}\right), 1.85-2.05$ (m, $\left.2 \mathrm{H} ; \mathrm{C}^{5} \mathrm{H}_{2}\right), 3.40-3.50\left(\mathrm{~m}, 2 \mathrm{H} ; \mathrm{CHHCH}_{3}\right), 3.55-3.65\left(\mathrm{~m}, 2 \mathrm{H} ; \mathrm{CHHCH}_{3}\right)$, $4.43\left(\mathrm{t},{ }^{3} \mathrm{~J}=6.0 \mathrm{~Hz}, 1 \mathrm{H} ; \mathrm{CH}\left(\mathrm{OC}_{2} \mathrm{H}_{5}\right)\right), 5.07 \mathrm{ppm}\left(\mathrm{t},{ }^{3} \mathrm{~J}=7.2 \mathrm{~Hz}, 1 \mathrm{H}\right.$; $\left.\mathrm{C}^{6} \mathrm{H}\right) .{ }^{13} \mathrm{C}$ NMR $\left(100 \mathrm{MHz}, \mathrm{CDCl}_{3}, 25^{\circ} \mathrm{C}, \mathrm{TMS}\right): \delta_{\mathrm{C}}=15.38\left(\mathrm{CH}_{2} \mathrm{CH}_{3}\right)$, $17.54\left(C^{8}\right), 19.42\left(C^{10}\right), 25.46\left(C^{5}\right), 25.62\left(C^{9}\right), 31.02\left(C^{1}\right), 31.63$ $\left(C^{2}\right), 32.22\left(C^{3}\right), 36.91\left(C^{4}\right), 60.67\left(\mathrm{CH}_{2} \mathrm{CH}_{3}\right), 60.74\left(\mathrm{CH}_{2} \mathrm{CH}_{3}\right), 103.28$ $\left(\mathrm{CH}\left(\mathrm{OC}_{2} \mathrm{H}_{5}\right)\right), 124.90\left(C^{6}\right), 131.04 \mathrm{ppm}\left(C^{7}\right)$.

Data for 8,8-diethoxy-2,6,7-trimethyloct-2-ene (2e, shorter GC retention time compared to 2d): MS (70 eV, EI): $\mathrm{m} / z$ (\%): 196 (2) [ $\left.\mathrm{M}^{+}-\mathrm{C}_{2} \mathrm{H}_{5} \mathrm{OH}\right], 135$ (19), 103 (100), 95 (35), 75 (83), 69 (23).

\section{Results and discussion}

We have studied the behavior of linalool (1a) and $\beta$-citronellene (2a) under the hydroformylation conditions in toluene and ethanol solutions using $[\mathrm{Rh}(\mathrm{COD})(\mathrm{OMe})]_{2}$ as a catalyst precursor in the presence of $\mathrm{PPh}_{3}$ or tris( $\mathrm{O}^{\mathrm{t}}$ butylphenyl $)$ phosphite, $\mathrm{P}\left(\mathrm{O}-\mathrm{O}_{-}{ }^{\mathrm{t}} \mathrm{BuPh}\right)_{3}$, 
Table 1

Rhodium catalyzed hydroformylation of linalool (1a). ${ }^{\text {a }}$

\begin{tabular}{|c|c|c|c|c|c|c|}
\hline Run & Ligand & $\mathrm{P} / \mathrm{Rh}$ & Time (h) & Conversion (\%) & $\operatorname{TOF}\left(\mathrm{h}^{-1}\right)$ & Selectivity for $\mathbf{1 c}(\%)$ (cis/trans) \\
\hline $1^{\mathrm{b}}$ & $\mathrm{PPh}_{3}$ & 10 & 6.0 & 100 & 38 & $94(93 / 7)$ \\
\hline $2^{\mathrm{b}, \mathrm{c}}$ & $\mathrm{P}\left(\mathrm{O}-\mathrm{O}-{ }^{\mathrm{t}} \mathrm{BuPh}\right)_{3}$ & 10 & 0.5 & 96 & 385 & $87(92 / 8)$ \\
\hline $3^{\mathrm{d}}$ & $\mathrm{P}\left(\mathrm{O}-\mathrm{o}-{ }^{\mathrm{t}} \mathrm{BuPh}\right)_{3}$ & 10 & 1.5 & 100 & 400 & $98(89 / 11)$ \\
\hline $4^{\mathrm{d}}$ & $\mathrm{P}\left(\mathrm{O}-\mathrm{O}-{ }^{\mathrm{t}} \mathrm{BuPh}\right)_{3}$ & 20 & 2.0 & 99 & 233 & $99(87 / 13)$ \\
\hline $5^{\mathrm{d}}$ & $\mathrm{P}\left(\mathrm{O}-\mathrm{o}-{ }^{\mathrm{t}} \mathrm{BuPh}\right)_{3}$ & 50 & 3.0 & 100 & 183 & $99(85 / 15)$ \\
\hline $6^{\mathrm{d}}$ & $\mathrm{P}\left(\mathrm{O}-\mathrm{o}-{ }^{\mathrm{t}} \mathrm{BuPh}\right)_{3}$ & 5 & 1.5 & 98 & 350 & $99(91 / 10)$ \\
\hline $7^{\mathrm{d}}$ & $\mathrm{P}\left(\mathrm{O}-\mathrm{O}-{ }^{\mathrm{t}} \mathrm{BuPh}\right)_{3}$ & 1 & 1.5 & 94 & 300 & $91(94 / 6)$ \\
\hline $8^{\mathrm{d}, \mathrm{e}}$ & None & - & 6.0 & 12 & 10 & $85(30 / 70)$ \\
\hline $9^{\mathrm{d}}$ & $\mathrm{PPh}_{3}$ & 5 & 21.0 & 47 & 33 & $89(20 / 80)$ \\
\hline
\end{tabular}

a For most of the runs the reaction time is given for nearly complete conversions. Conversion and selectivity are based on the substrate reacted. TOF - initial turnover frequency (mol of the substrate converted per mol of Rh per hour).

b Conditions: linalool $(0.10 \mathrm{M}),[\mathrm{Rh}(\mathrm{COD})(\mathrm{OMe})]_{2}(0.25 \mathrm{mM})$, ligand $(5.0 \mathrm{mM}), 50{ }^{\circ} \mathrm{C}, 80 \mathrm{~atm}\left(\mathrm{CO} / \mathrm{H}_{2}=1 / 1\right)$, toluene.

c Average TOF is given as the reaction was too fast.

d Conditions: linalool $(0.30 \mathrm{M})$, $[\mathrm{Rh}(\mathrm{COD})(\mathrm{OMe})]_{2}(0.30 \mathrm{mM}), 40^{\circ} \mathrm{C}, 20 \mathrm{~atm}\left(\mathrm{CO} / \mathrm{H}_{2}=1 / 1\right)$, toluene.

e $50^{\circ} \mathrm{C}$.

as P-donor auxiliary ligands. The hydroformylation of linalool in toluene with the $\mathrm{Rh} / \mathrm{PPh}_{3}$ system has been described in our previous publication [23]; however, we have included some runs in the tables for comparison.

Under the hydroformylation conditions in toluene, both substrates gave one or two major products derived from the direct carbonylation of their terminal double bonds. No reactivity of the internal double bond was observed even in the system with the bulky $\mathrm{P}\left(\mathrm{O}-\mathrm{o}_{-}{ }^{\mathrm{t}} \mathrm{BuPh}\right)_{3}$ ligand. When the reactions were performed in ethanol, the corresponding acetals appeared in the reaction mixtures due to the in situ acetalization of the primarily formed products. It is important to point out that the formation of acetals occurred without using any additional acid co-catalyst. The regioand stereoselectivity of the reaction steps was remarkably dependent on the reaction variables and the nature of the auxiliary phosphorous ligand. The substrates and corresponding products are numbered in the present communication by the same number with the addition of the letter "a" to indicate the substrate and other letters to indicate the products derived from this substrate. In all products, we have maintained a carbon numbering conventionally used for starting monoterpene molecules. The total selectivity for the hydroformylation products in most of the runs exceeded 95\% for both substrates, with GC yields for some individual products being nearly quantitative under optimized conditions.

\subsection{Hydroformylation of linalool in toluene solutions}

Hydroformylation of linolool in the presence of $\mathrm{PPh}_{3}$ gave hemiacetal 1c as the main product (Table 1 , run 1 , Scheme 1 ). This product formally results from the intramolecular cyclization of the primarily formed hydroxy aldehyde $\mathbf{1 b}$, which we have never detected in the reaction solutions. Hemiacetal was formed almost exclusively with a cis configuration of the methylpentenyl and hydroxyl groups with respect to the tetrahydrofuran ring. The use of the $\mathrm{P}\left(\mathrm{O}-\mathrm{O}^{-}{ }^{\mathrm{t}} \mathrm{BuPh}\right)_{3}$ ligand instead of $\mathrm{PPh}_{3}$ remarkably increased the reactivity of linalool (Table 1 , run 2 vs. run 1 ). The reaction in run 2 was too fast for measuring the initial rate by GC being completed for $30 \mathrm{~min}$. However, even the average turnover frequency (TOF) in the run with $\mathrm{P}\left(\mathrm{O}-\mathrm{o}^{-}{ }^{\mathrm{t}} \mathrm{BuPh}\right)_{3}$ was more than ten times higher than the initial TOF in the reaction performed with $\mathrm{PPh}_{3}$ under the same conditions. In a further study we decreased the temperature and the pressure to slow down the reactions.

The hydroformylation of linalool with the $\mathrm{Rh} / \mathrm{P}\left(\mathrm{O}-\mathrm{O}^{\mathrm{t}}{ }^{\mathrm{t}} \mathrm{BuPh}\right)_{3}$ system at $40^{\circ} \mathrm{C}$ and $20 \mathrm{~atm}$ resulted in nearly quantitative yield of

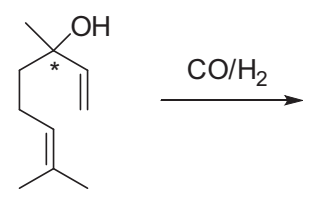

$1 a$

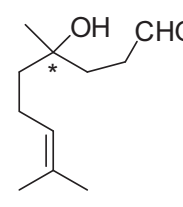

$1 \mathrm{~b}$

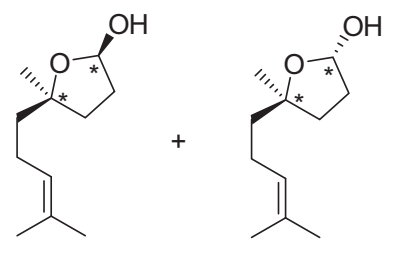

1c (cis) 1c (trans)<smiles>CCOCC(C)O</smiles>

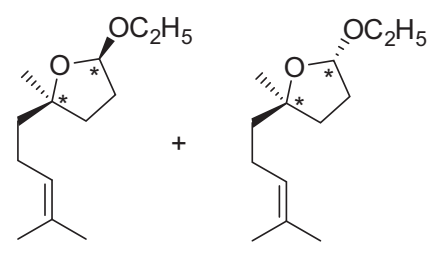

1d (cis)

1d (trans)

Scheme 1. Hydroformylation/acetalization of linalool (1a). 


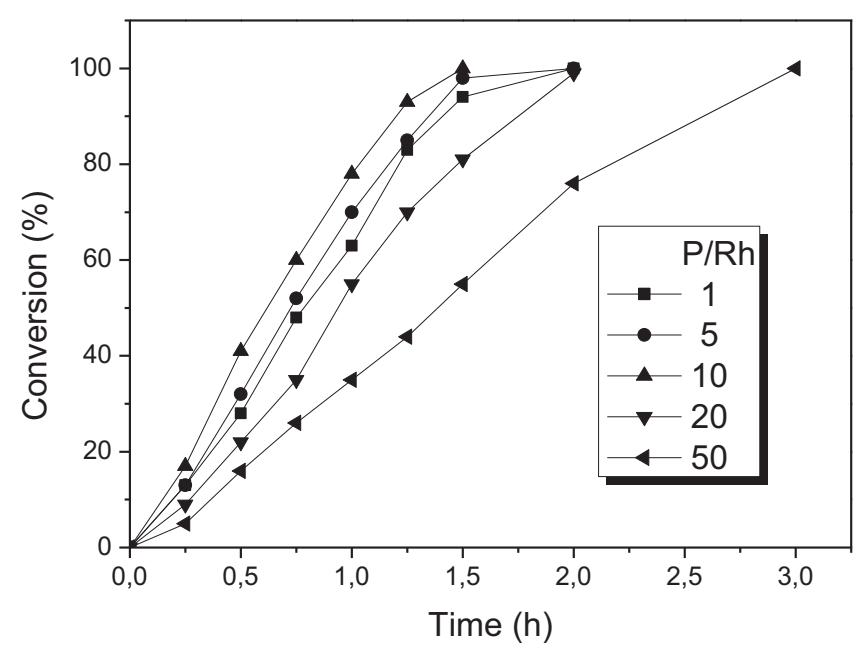

Fig. 1. Hydroformylation of linalool catalyzed by $\mathrm{Rh} / \mathrm{P}\left(\mathrm{O}-\mathrm{o}^{\mathrm{t}}{ }^{\mathrm{B}} \mathrm{BuPh}\right)_{3}$ : effect of the $\mathrm{P} / \mathrm{Rh}$ ratio. Conditions: linalool $(0.30 \mathrm{M}),[\mathrm{Rh}(\mathrm{COD})(\mathrm{OMe})]_{2}(0.30 \mathrm{mM}), 40^{\circ} \mathrm{C}, 20 \mathrm{~atm}$ $\left(\mathrm{CO} / \mathrm{H}_{2}=1 / 1\right)$, toluene.

hemiacetal 1c (ca. 90\% cis, Table 1, runs 3-5). Kinetic curves for the runs with various $\mathrm{P} / \mathrm{Rh}$ ratios (runs $2-7$ in Table 1 ) are presented in Fig. 1. A slight acceleration can be seen when the $\mathrm{P} / \mathrm{Rh}$ ratio increases from 1 to 10 , whereas further addition of the ligand decreases the reaction rate. The kinetic curves are nearly straight lines up to $80-90 \%$ conversions even at $\mathrm{P} / \mathrm{Rh}=50$, indicating that the substrate competes successfully with the ligand for the coordination sites on rhodium. In other words, the substrate reacts with rhodium quite readily and a majority of the metal centers, even at high conversions and high ligand concentrations, contain strongly coordinated linalool or fragments derived from linalool. In most of the runs, the cis isomer of 1c predominated (85-95\%), with its relative amounts being only slightly decreased with the increase in the ligand concentration.

An unexpected accelerating effect of $\mathrm{PPh}_{3}$ on the reactivity of linolool has been reported in our previous publication [23]. In the present work, we have found that the acceleration is much more pronounced with the $\mathrm{P}\left(\mathrm{O}-\mathrm{o}_{-}{ }^{\mathrm{B}} \mathrm{BuPh}\right)_{3}$ ligand. In the absence of the $\mathrm{P}$ ligand, only a $12 \%$ conversion was observed for $6 \mathrm{~h}$, while with small amounts of $\mathrm{P}\left(\mathrm{O}-\mathrm{O}-{ }^{\mathrm{t}} \mathrm{BuPh}\right)_{3}$ the reaction was nearly completed in $1.5 \mathrm{~h}$ even at lower temperature (cf. runs 7 and 8 , Table 1 ). In most modified rhodium systems, the hydroformylation rate decreases with the increase in the P-ligand concentration due to the competition between the ligand and the substrate for coordination sites on rhodium. The unusual effect observed at the hydroformylation of linalool can be explained by the chelation of the substrate on rhodium through the coordination of both the double bond and the hydroxyl group [23]. The increase in the P-ligand concentration favors the cleavage of the inactive chelates allowing the proper positioning of the $\mathrm{C}-\mathrm{C}$ double bond for the hydride migration. It is remarkable that the presence of only $0.2 \mathrm{~mol} \%$ of $\mathrm{P}\left(\mathrm{O}-\mathrm{o}^{\mathrm{t}}{ }^{\mathrm{BuPh}}\right)_{3}$ $(\mathrm{P} / \mathrm{Rh}=1)$ is sufficient to overcome the chelation problem and to perform the hydroformylation of linolool rapidly $\left(\mathrm{TOF}=300 \mathrm{~h}^{-1}\right.$ ) and selectively under mild conditions (Table 1, run 7).

The strong effect of the ligand nature on the hydroformylation of linalool is illustrated in Fig. 2, which shows the kinetic curves for the reactions with $\mathrm{PPh}_{3}$ and $\mathrm{P}\left(\mathrm{O}-\mathrm{O}_{-}{ }^{\mathrm{t}} \mathrm{BuPh}\right)_{3}$ under the same conditions (Table 1, runs 6 and 9 ). Only $20 \%$ of linalool was converted for $8 \mathrm{~h}$ in the presence of $\mathrm{PPh}_{3}$, with the 3-h induction period being observed on the reaction profile. Nevertheless, the reaction in the presence of $\mathrm{P}\left(\mathrm{O}-\mathrm{o}-{ }^{\mathrm{t}} \mathrm{BuPh}\right)_{3}$ occurred more than ten times faster without any induction period (TOF $=350$ vs. 33 ). The existence of the induction

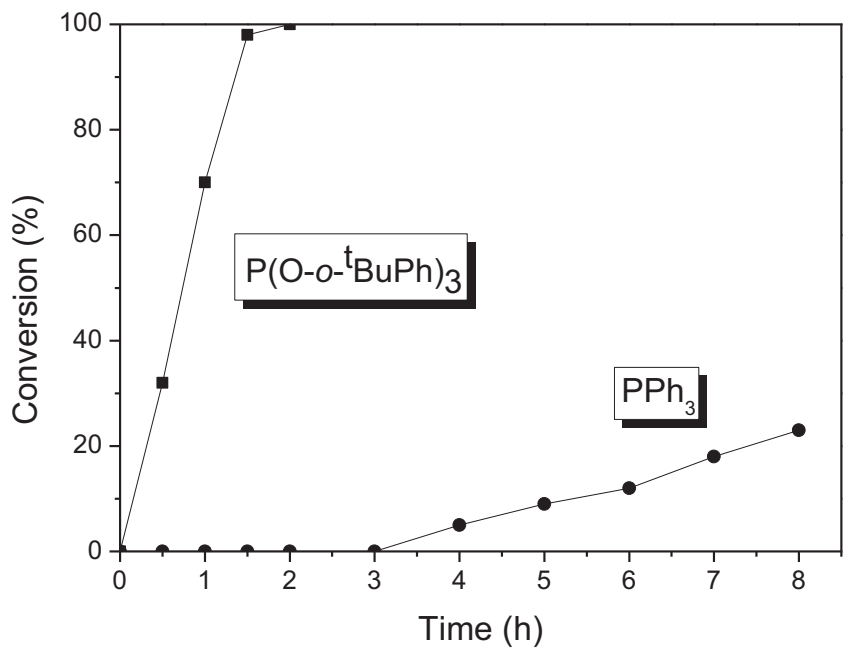

Fig. 2. Rhodium catalyzed hydroformylation of linalool: ligand effect. Conditions: linalool $(0.30 \mathrm{M}),[\mathrm{Rh}(\mathrm{COD})(\mathrm{OMe})]_{2}(0.30 \mathrm{mM})$, ligand $(3.0 \mathrm{mM}), 40^{\circ} \mathrm{C}, 20 \mathrm{~atm}$ $\left(\mathrm{CO} / \mathrm{H}_{2}=1 / 1\right)$, toluene.

period in the $\mathrm{Rh} / \mathrm{PPh}_{3}$ system supports the chelation hypothesis: at the beginning of the reaction, inactive rhodium-linalool chelate complexes should be opened by the $\mathrm{PPh}_{3}$ coordination [23]. A great advantage of using $\mathrm{P}\left(\mathrm{O}-\mathrm{o}-{ }^{\mathrm{t}} \mathrm{BuPh}\right)_{3}$ consists in a high efficiency of this ligand to prevent the linalool chelation and/or to break up rhodiumlinalool chelates. Even in the reaction with small amounts of $\mathrm{P}(\mathrm{O}-$ $\left.{ }-{ }^{\mathrm{t}} \mathrm{BuPh}\right)_{3}$, no induction period was observed on the kinetic curves.

The effect of the ligand nature on the stereochemistry of the hemiacetal deserves a special attention. On changing the ligand from $\mathrm{P}\left(\mathrm{O}-\mathrm{O}^{-}{ }^{\mathrm{t}} \mathrm{BuPh}\right)_{3}$ to $\mathrm{PPh}_{3}$ under the same reaction conditions, the stereoselectivity of cyclization was virtually switched from cis to trans (Table 1, runs 6 and 9). This result contradicts with the reaction path shown in Scheme 1, in which two reaction steps occur consecutively with no participation of rhodium in the cyclization step. A spontaneous cyclization of aldehyde $\mathbf{1 b}$ should give preferably the thermodynamically more stable trans isomer of 1c and stereochemistry should not depend on the ligands on the rhodium species. A strong ligand effect argues for the suggestion that the interaction between the hydroxyl and carbonyl groups leading to the intramolecular cyclization could also occur in the rhodium acyl intermediate before its hydrogenolysis to give aldehyde 1b [23]. The cyclization of the rhodium acyl intermediate should give preferably a less hindered cyclic rhodium intermediate in which a bulky rhodium/P(O- $\left.{ }^{-}{ }^{\mathrm{t}} \mathrm{BuPh}\right)_{3}$ fragment and methylpentenyl group are at the opposite sides of the tetrahydrofuran ring. The hydrogenolysis of the trans cyclic rhodium intermediate will give hemiacetal 1c with the methylpentenyl and hydroxyl groups in a cis position.

The inversion of stereochemistry of hemiacetal from cis to trans can also be achieved by the increase in the hydrogen pressure as higher hydrogen concentrations favor the hydrogenolysis of the rhodium acyl intermediate before its cyclization. At $20 \mathrm{~atm}$ $\left(\mathrm{CO} / \mathrm{H}_{2}=1 / 1\right)$, the cis isomer accounted for ca. $90 \%$ of the mass balance; whereas at $80 \mathrm{~atm}$, both isomers were formed in comparable amounts (Table 2, run 1 vs. run 3). Moreover, increasing only the hydrogen pressure allowed to obtain the trans isomer in nearly $80 \%$ yield (Table 2, run 4). On the other hand, the increase in the reaction temperature switched stereoselectivity again to cis isomer (cf. run 3 in Table 2 and run 2 in Table 1 ). Thus, through the choice of reaction variables we can control stereochemistry of the hydroformylation product derived from linalool. Each of two isomers of hemiacetal 1c can be obtained in 75-90\% individual yields under appropriate conditions. 
Table 2

Rhodium catalyzed hydroformylation of linalool (1a): effect of pressure ${ }^{\mathrm{a}}$

\begin{tabular}{|c|c|c|c|c|}
\hline Run & $\mathrm{P}(\mathrm{CO})(\mathrm{atm})$ & $\mathrm{P}\left(\mathrm{H}_{2}\right)(\mathrm{atm})$ & $\operatorname{TOF}\left(h^{-1}\right)$ & Selectivity for $\mathbf{1 c}(\%)$ (cis/trans) \\
\hline 1 & 10 & 10 & 400 & $98(89 / 11)$ \\
\hline 2 & 25 & 25 & 350 & $97(86 / 14)$ \\
\hline 3 & 40 & 40 & 330 & $95(42 / 58)$ \\
\hline $4^{\mathrm{b}}$ & 10 & 40 & 1830 & $96(23 / 77)$ \\
\hline 5 & 40 & 10 & 100 & $97(91 / 9)$ \\
\hline
\end{tabular}

a Conditions: linalool $(0.30 \mathrm{M}),[\mathrm{Rh}(\mathrm{COD})(\mathrm{OMe})]_{2}(0.30 \mathrm{mM}), \mathrm{P}\left(\mathrm{O}-\mathrm{o}^{\mathrm{t}}{ }^{\mathrm{BuPh}}\right)_{3}(6.0 \mathrm{mM}), \mathrm{P} / \mathrm{Rh}=10,40^{\circ} \mathrm{C}$, toluene. Selectivity at nearly complete conversions is given and is based on the substrate reacted. TOF - initial turnover frequency (mol of the substrate converted per mol of Rh per hour).

b Average TOF is given as the reaction was too fast.

Table 3

Rhodium catalyzed hydroformylation of $\beta$-citronellene (2a). ${ }^{\mathrm{a}}$

\begin{tabular}{|c|c|c|c|c|c|c|c|c|}
\hline \multirow[t]{2}{*}{ Run } & \multirow[t]{2}{*}{ Ligand } & \multirow[t]{2}{*}{$\mathrm{P} / \mathrm{Rh}$} & \multirow[t]{2}{*}{$\mathrm{P}(\mathrm{CO})(\mathrm{atm})$} & \multirow[t]{2}{*}{$\mathrm{P}\left(\mathrm{H}_{2}\right)(\mathrm{atm})$} & \multirow[t]{2}{*}{ Time $(\mathrm{h})$} & \multirow[t]{2}{*}{$\operatorname{TOF}\left(h^{-1}\right)$} & \multicolumn{2}{|c|}{ Selectivity (\%) } \\
\hline & & & & & & & $2 \mathbf{b}$ & $2 c$ \\
\hline 1 & $\mathrm{PPh}_{3}$ & 2 & 40 & 40 & 4.0 & 54 & 74 & 21 \\
\hline 2 & $\mathrm{PPh}_{3}$ & 10 & 40 & 40 & 7.0 & 42 & 84 & 15 \\
\hline 3 & $\mathrm{PPh}_{3}$ & 20 & 40 & 40 & 9.0 & 36 & 84 & 15 \\
\hline 4 & $\mathrm{PPh}_{3}$ & 40 & 40 & 40 & 10.0 & 34 & 84 & 15 \\
\hline 5 & $\mathrm{PPh}_{3}$ & 10 & 20 & 20 & 6.0 & 44 & 84 & 15 \\
\hline 6 & $\mathrm{PPh}_{3}$ & 10 & 40 & 20 & 9.0 & 26 & 83 & 16 \\
\hline 7 & $\mathrm{PPh}_{3}$ & 10 & 20 & 40 & 4.0 & 80 & 84 & 15 \\
\hline 8 & None & - & 40 & 40 & 1.0 & 200 & 70 & 21 \\
\hline 9 & 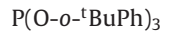 & 10 & 40 & 40 & 0.75 & 520 & 68 & 31 \\
\hline 10 & $\mathrm{P}\left(\mathrm{O}-0-{ }^{\mathrm{t}} \mathrm{BuPh}\right)_{3}$ & 20 & 40 & 40 & 0.75 & 480 & 68 & 32 \\
\hline $11^{\mathrm{b}}$ & $\mathrm{P}(\mathrm{OPh})_{3}$ & 10 & 40 & 40 & 3.0 & 9 & 55 & 10 \\
\hline
\end{tabular}

a Conditions: $\beta$-citronellene $(0.10 \mathrm{M}),[\mathrm{Rh}(\mathrm{COD})(\mathrm{OMe})]_{2}(0.25 \mathrm{mM}), 50{ }^{\circ} \mathrm{C}$, toluene. Conversion and selectivity are based on the substrate reacted; the reaction time is given for nearly complete conversions. TOF - initial turnover frequency ( $\mathrm{mol}$ of the substrate converted per mol of Rh per hour).

b $14 \%$ conversion for $3 \mathrm{~h}$

A concerned to the effects of the carbon monoxide and hydrogen pressure on the hydroformylation of linalool in the $\mathrm{Rh} / \mathrm{P}(\mathrm{O}-\mathrm{O}-$ $\left.{ }^{t} \mathrm{BuPh}\right)_{3}$ system, the general trends are similar to those observed in the $\mathrm{Rh} / \mathrm{PPh}_{3}$ system [23]: a nearly first positive order in hydrogen and also nearly first negative order in carbon monoxide (Table 2). The increase in the total pressure decreased only slightly the reaction rates (Table 2, runs 1-3), reflecting a net result of the opposite kinetic effects of the gas reagents. The accelerating effect of hydrogen suggests that the oxidative addition of hydrogen to the rhodium acyl intermediate seems to be a rate-determining step at the linalool hydroformylation.

\subsection{Hydroformylation of $\beta$-citronellene in toluene solutions}

The hydroformylation of $\beta$-citronellene (2a) occurred smoothly in toluene solutions in the presence of $\mathrm{PPh}_{3}$, with selectively being high even at low $\mathrm{P} / \mathrm{Rh}$ ratio (Table 3 , run 1 ). Two aldehydes resulted from the hydroformylation of the terminal double bond were<smiles>C=C[C+](C)CCC=C(C)C</smiles>

$2 a$

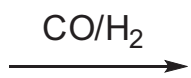

$2 b$<smiles>[R]C(C)C(C)=CCC=C(C)C</smiles>

2c<smiles>[R]C(C)CCCC(C)OCC</smiles>

Scheme 2. Hydroformylation/acetalization of $\beta$-citronellene (2a). 


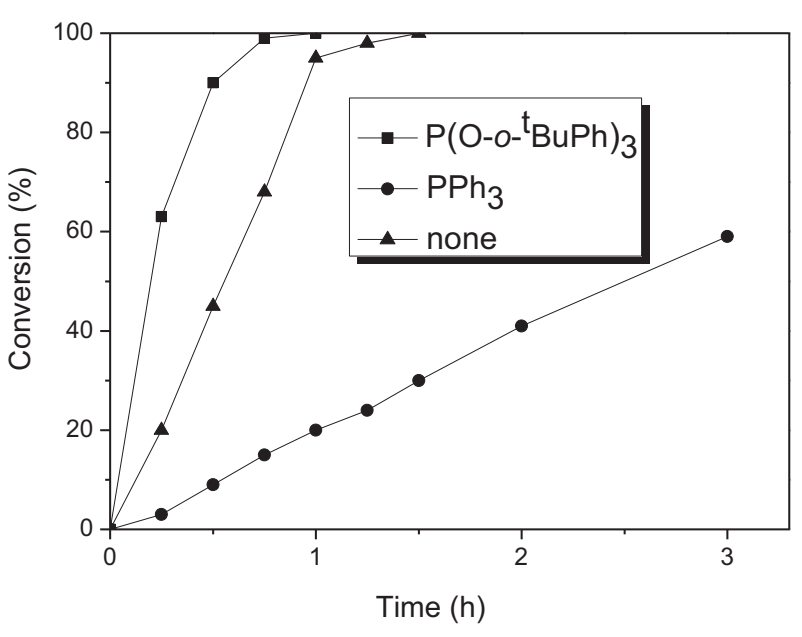

Fig. 3. Rhodium catalyzed hydroformylation of $\beta$-citronellene: ligand effect. Conditions: $\beta$-citronellene $(0.10 \mathrm{M}),[\mathrm{Rh}(\mathrm{COD})(\mathrm{OMe})]_{2}(0.25 \mathrm{mM})$, ligand $(5.0 \mathrm{mM}), 50^{\circ} \mathrm{C}$, $80 \mathrm{~atm}\left(\mathrm{CO} / \mathrm{H}_{2}=1 / 1\right)$, toluene.

formed with a 95\% combined selectivity (Scheme 2), the linear isomer (2b) accounting for $74 \%$ of the mass balance. The branched aldehyde (2c) was formed as a mixture of two diastereoisomers, $(2 R, 3 R)$ and $(2 S, 3 R)$, detected in nearly equal amounts as the molecule of starting $\beta$-citronellene has $R$ configuration at asymmetric carbon $\mathrm{C}-3$. The diastereoisomers were not GC separable under the conditions used; however, their molecules showed different NMR spectra.

The increase in $\mathrm{P} / \mathrm{Rh}$ to 10 expectedly decreased the reaction rate and improved selectivity for aldehydes, which were formed in a nearly quantitative combined yield. A further increase in the phosphine concentration did not affect significantly the reaction.

In the absence of the P-ligand, the hydroformylation of $\beta$ citronellene occurred faster than in the $\mathrm{Rh} / \mathrm{PPh}_{3}$ system, albeit with lower selectivity (Table 3 , cf. run 8 and run 2 ). This result is expected for simple non-functionalized non-conjugated alkenes due to the competition between the phosphine and the substrate for the coordination sites on rhodium. On the other hand, a significant accelerating effect of the phosphite ligand, $\mathrm{P}\left(\mathrm{O}-\mathrm{O}^{-}{ }^{\mathrm{t}} \mathrm{BuPh}\right)_{3}$, as compared to the unmodified system is much less expected. The reaction in the presence of $\mathrm{P}\left(\mathrm{O}-\mathrm{o}_{-}{ }^{\mathrm{t}} \mathrm{BuPh}\right)_{3}$ was 2.5 times faster than in the absence of the P-ligand and more than ten times faster than with $\mathrm{PPh}_{3}$ (Table 3, runs 2, 8 and 9; Fig. 3).

The accelerating effect of $\mathrm{P}\left(\mathrm{O}-\mathrm{O}_{-}{ }^{\mathrm{t}} \mathrm{BuPh}\right)_{3}$ as compared to $\mathrm{PPh}_{3}$ can be explained by the large cone angle of the former, which disfavors the formation of bis(phosphorous ligand) rhodium species. At the same $\mathrm{P} / \mathrm{Rh}$ ratios, for the $\mathrm{Rh} / \mathrm{P}\left(\mathrm{O}-{ }_{-}-{ }^{t} \mathrm{BuPh}\right)_{3}$ system a larger part of rhodium exists as mono(phosphorous ligand) species, which are more active in hydroformylation. Furthermore, the weaker $\sigma$ basicity combined with the stronger $\pi$-acidity of $\mathrm{P}\left(\mathrm{O}-{ }_{-}{ }^{-} \mathrm{BuPh}\right)_{3}$ ( $\chi$-value of 30.50 vs. 13.25 for $\mathrm{PPh}_{3}$ ) favors the more facile CO dissociation and the stronger alkene association with rhodium [38]. In the presence of phosphite, the initial reaction rates depended only slightly on the ligand concentration (Table 4, runs $1-3$ ). Thus, the $\mathrm{P} / \mathrm{Rh}$ ratio of 10 is enough to keep most of rhodium coordinated to one $\mathrm{P}\left(\mathrm{O}-\mathrm{o}^{-}{ }^{\mathrm{t}} \mathrm{BuPh}\right)_{3}$ and, even at $\mathrm{P} / \mathrm{Rh}=30$, bis(phosphorous ligand) species are not formed in appreciable amounts. On the other hand, the reaction with less bulky phosphite, $\mathrm{P}(\mathrm{OPh})_{3}$, was much slower than that with $\mathrm{P}\left(\mathrm{O}-\mathrm{o}^{\mathrm{t}}{ }^{\mathrm{BuPh}}\right)_{3}$ (Table 3 , run 11$)$.

We have also studied the effects of the carbon monoxide and hydrogen pressure on the hydroformylation of $\beta$-citronellene (Tables 3 and 4). The general trends are similar for both ligands: a positive order in hydrogen (Table 3, cf. runs 2 and 6; Table 4, cf. runs 1 and 6 ) and an inverse order in carbon monoxide (Table 3, cf.
Table 4

Hydroformylation of $\beta$-citronellene (2a) catalyzed by $\mathrm{Rh} / \mathrm{P}\left(\mathrm{O}-0-{ }^{\mathrm{t}} \mathrm{BuPh}\right)_{3}{ }^{\text {a }}$

\begin{tabular}{llllllll}
\hline Run & $\mathrm{P} / \mathrm{Rh}$ & $\begin{array}{l}\mathrm{P}(\mathrm{CO}) \\
(\mathrm{atm})\end{array}$ & $\begin{array}{l}\mathrm{P}\left(\mathrm{H}_{2}\right) \\
(\mathrm{atm})\end{array}$ & Time $(\mathrm{h})$ & $\mathrm{TOF}\left(\mathrm{h}^{-1}\right)$ & \multicolumn{2}{l}{$\begin{array}{l}\text { Selectivity } \\
(\%)\end{array}$} \\
\cline { 5 - 8 } & & & & & & $\mathbf{2 b}$ & $\mathbf{2 c}$ \\
\hline 1 & 10 & 40 & 40 & 1.5 & 240 & 68 & 31 \\
2 & 20 & 40 & 40 & 1.5 & 200 & 66 & 33 \\
3 & 30 & 40 & 40 & 1.5 & 240 & 66 & 33 \\
4 & 10 & 20 & 20 & 1.5 & 250 & 68 & 31 \\
5 & 10 & 20 & 40 & 0.75 & 360 & 67 & 32 \\
6 & 10 & 40 & 20 & 2.0 & 150 & 66 & 32 \\
\hline
\end{tabular}

a Conditions: $\beta$-citronellene $(0.10 \mathrm{M}), \quad[\mathrm{Rh}(\mathrm{COD})(\mathrm{OMe})]_{2} \quad(0.25 \mathrm{mM}), \quad 40^{\circ} \mathrm{C}$, toluene. Conversion and selectivity are based on the substrate reacted; the reaction time is given for nearly complete conversions. TOF - initial turnover frequency (mol of the converted substrate per mol of Rh per hour).

runs 2 and 7; Table 4, cf. runs 1 and 5). The variation in the total pressure of the equimolar gas mixture had no influence on the reaction rates due to the opposite kinetic effects of the gas reagents (Table 3, cf. runs 2 and 5; Table 4, cf. runs 1 and 4). The positive order in hydrogen observed at relatively high pressures suggests that the hydrogenolysis of the rhodium acyl intermediate seems to be the most likely rate-determining step in the hydroformylation of $\beta$-citronellene.

The results of the kinetic study are in agreement with the observed accelerating effect of $\mathrm{P}\left(\mathrm{O}-\mathrm{O}-{ }^{\mathrm{t}} \mathrm{BuPh}\right)_{3}$ in the hydroformylation of $\beta$-citronellene as compared to the unmodified system. It is reasonable to expect that a higher steric hindrance in the active rhodium species containing the bulky $\mathrm{P}\left(\mathrm{O}-\mathrm{o}^{\mathrm{t}}{ }^{\mathrm{BuPh}}\right)_{3}$ ligand will result in lower reaction rates. However, the reaction occurs much faster in the presence of $\mathrm{P}\left(\mathrm{O}-\mathrm{o}^{\mathrm{t}}{ }^{\mathrm{BuPh}}\right)_{3}$ implying that electronic rather than steric parameters dominate in this system. Considering that $\mathrm{P}\left(\mathrm{O}-\mathrm{O}^{\mathrm{t}}{ }^{\mathrm{BuPh}}\right)_{3}$ is more basic ligand than $\mathrm{CO}$, the rhodium center should be more electron rich as compared to the center with only carbonyl ligands. Therefore, the most likely rate-determing step which involves the oxidative addition of hydrogen should be accelerated by the presence of the phosphite ligand on rhodium. It is also important that in the $\mathrm{Rh} / \mathrm{P}\left(\mathrm{O}-\mathrm{O}_{-}{ }^{\mathrm{t}} \mathrm{BuPh}\right)_{3}$ system (differently from the $\mathrm{Rh} / \mathrm{PPh}_{3}$ system) the formation of less active bis(phosphorous ligand) rhodium species is highly disfavored by the ligand bulkiness. Bulky phosphite ligands usually show much better performance in hydroformylation compared to phosphine ligands due to the combination of steric and electronic effects $[39,40]$.

\subsection{Hydroformylation of linalool and $\beta$-citronellene in ethanol solutions}

The hydroformylation of linalool and $\beta$-citronellene was performed also in ethanol, a renewable, low cost and environmentally friendly solvent, to substitute oil industry derivatives such as toluene, commonly used in this reaction. The solvent promoted a significant kinetic effect on the reactions and, under certain conditions, changed the product nature. In general, the reactions with both substrates were ca. two times faster in ethanol than in toluene and showed nearly the same combined selectivity for the hydroformylation products.

Linalool was virtually inactive in ethanol solutions in the absence of phosphorous ligand, similarly to what was found in toluene, probably due to the formation of chelate complexes between linolool and rhodium (Table 5, run 1 ). The addition of $\mathrm{PPh}_{3}$ induced the reactivity of linalool toward hydroformylation by cleavage of chelates, with a maximum activity being observed at $\mathrm{P} / \mathrm{Rh}=10-20$ (Table 5 , runs 2-6). The reaction gives almost quantitatively the cyclic acetal 1d, which formally results from the etherification of hemiacetal 1c with ethanol (Scheme 1). In most 
Table 5

Rhodium catalyzed hydroformylation of linalool (1a) in ethanol. ${ }^{a}$

\begin{tabular}{|c|c|c|c|c|c|}
\hline Run & Ligand & $\mathrm{P} / \mathrm{Rh}$ & Time (h) & $\operatorname{TOF}\left(\mathrm{h}^{-1}\right)$ & Selectivity for $\mathbf{1 d}(\%)$ (cis/trans) \\
\hline 1 & None & - & - & $<0.5$ & $99(48 / 52)$ \\
\hline 2 & $\mathrm{PPh}_{3}$ & 2 & 12 & 50 & $98(48 / 52)$ \\
\hline 3 & $\mathrm{PPh}_{3}$ & 5 & 4 & 150 & $97(73 / 27)$ \\
\hline 4 & $\mathrm{PPh}_{3}$ & 10 & 4 & 190 & $98(74 / 26)$ \\
\hline 5 & $\mathrm{PPh}_{3}$ & 20 & 4 & 185 & $98(80 / 20)$ \\
\hline $6^{\mathrm{b}}$ & $\mathrm{PPh}_{3}$ & 50 & 4 & 84 & $96(95 / 5)$ \\
\hline 7 & $\mathrm{P}\left(\mathrm{O}-\mathrm{o}-{ }^{\mathrm{t}} \mathrm{BuPh}\right)_{3}$ & 2 & 2 & 200 & $97(62 / 38)$ \\
\hline 8 & $\mathrm{P}\left(\mathrm{O}-\mathrm{o}-{ }^{\mathrm{t}} \mathrm{BuPh}\right)_{3}$ & 5 & 0.8 & 520 & $97(66 / 34)$ \\
\hline $9^{c}$ & $\mathrm{P}\left(\mathrm{O}-\mathrm{o}-{ }^{\mathrm{t}} \mathrm{BuPh}\right)_{3}$ & 10 & 0.5 & 1000 & $97(77 / 23)$ \\
\hline $10^{c}$ & $\mathrm{P}\left(\mathrm{O}-\mathrm{o}-{ }^{\mathrm{t}} \mathrm{BuPh}\right)_{3}$ & 20 & 0.5 & 1000 & $97(85 / 15)$ \\
\hline $11^{\mathrm{c}}$ & $\mathrm{P}\left(\mathrm{O}-\mathrm{o}-{ }^{\mathrm{t}} \mathrm{BuPh}\right)_{3}$ & 30 & 0.5 & 1000 & $97(85 / 15)$ \\
\hline
\end{tabular}

a Conditions: linalool $(0.30 \mathrm{M}),[\mathrm{Rh}(\mathrm{COD})(\mathrm{OMe})]_{2}(0.30 \mathrm{mM}), 50^{\circ} \mathrm{C}, 20 \mathrm{~atm}\left(\mathrm{CO} / \mathrm{H}_{2}=1 / 1\right)$, ethanol. For most of the run the reaction time is given for nearly complete conversions. Conversion and selectivity are based on the substrate reacted. TOF - initial turnover frequency (mol of the substrate converted per mol of Rh per hour).

b $57 \%$ conversion for $4 \mathrm{~h}$.

c Average TOF is given as the reaction was too fast.

of the runs, small to medium amounts of $\mathbf{1 c}$ were detected in the reaction solutions at incomplete linalool conversions.

The use of $\mathrm{P}\left(\mathrm{O}-\mathrm{O}^{-}{ }^{\mathrm{t}} \mathrm{BuPh}\right)_{3}$ instead of $\mathrm{PPh}_{3}$ remarkably accelerated the hydroformylation of linalool in ethanol solutions (Table 5 , runs 7-11). The reactions in the presence of $\mathrm{P}\left(\mathrm{O}_{-} \mathrm{o}^{\mathrm{t}}{ }^{\mathrm{BuPh}}\right)_{3}$ were ca. 5 times faster than in the presence of $\mathrm{PPh}_{3}$ under the same conditions. Similarly to the $\mathrm{Rh} / \mathrm{PPh}_{3}$ system, the increase in the $\mathrm{P}\left(\mathrm{O}-\mathrm{O}^{\mathrm{t}}{ }^{\mathrm{BuPh}}\right)_{3} / \mathrm{Rh}$ ratio up to 10 resulted in higher reaction rates. The stereoselectivity of the cyclization step also strongly depended on the concentration of phosphorous ligand: cis and trans isomers of acetal were formed in comparable amounts at low $\mathrm{P} / \mathrm{Rh}$ ratios, whereas at high ligand concentrations the cis isomer became the major or the almost exclusive reaction product. Similar trends in stereoselectivity of the cyclization step were for both solvents and both ligands used in the present work. The cis isomers of cyclic hemiacetal 1c and its ethyl ether 1d arise from the less hindered cyclic rhodium complex (proposed as the reaction intermediate) and are preferred products in the solutions with relatively high concentrations of bulky phosphorous ligands. It is important to note that the efficient etherification of hemiacetal 1c occurs in the ethanol solutions under the hydroformylation conditions in the absence of any additional acid co-catalyst.

The hydroformylation of $\beta$-citronellene also readily occurs in ethanol solution giving aldehydes $\mathbf{2 b}$ and $\mathbf{2 c}$ and corresponding acetals $\mathbf{2 d}$ and $\mathbf{2 e}$ in a nearly quantitative combined yield (Table 6 , Scheme 2). In the unmodified system, the reaction at $40{ }^{\circ} \mathrm{C}$ was very slow showing ca. $50 \%$ conversion in $24 \mathrm{~h}$ (Table 6 , run 1 ). The introduction of $\mathrm{PPh}_{3}$ accelerated the reaction, which was completed in $24 \mathrm{~h}$, and promoted a partial acetalization of the aldehydes (Table 6 , runs 3 and 4). However, a really remarkable kinetic effect was promoted by $\mathrm{P}\left(\mathrm{O}-\mathrm{O}^{\mathrm{t}}{ }^{\mathrm{BuPh}}\right)_{3}$ : the initial reaction rates at the same $\mathrm{P} / \mathrm{Rh}$ ratio and under the same conditions were ca. 20 times higher with $\mathrm{P}\left(\mathrm{O}-\mathrm{O}^{\mathrm{t}} \mathrm{BuPh}\right)_{3}$ than with $\mathrm{PPh}_{3}$ (Table 6 , runs 2 and 3 vs. runs 4 and 5 ). At $P / R h=5$ the aldehydes were obtained in nearly quantitative combined yield, with only small amounts of corresponding acetals being observed at the end of the reaction (Table 6, run 4). A complete substrate conversion occurred in $1 \mathrm{~h}$. The increase in the $\mathrm{P}\left(\mathrm{O}-0-{ }^{\mathrm{t}} \mathrm{BuPh}\right)_{3}$ concentration (runs 5 and 6$)$ and in reaction temperature (runs 7 and 8 ) enhanced the acetalization activity of the catalyst. At $80^{\circ} \mathrm{C}$, a substantial part of the primarily formed aldehydes $\mathbf{2 b}$ and $\mathbf{2 c}$ was converted into corresponding acetals $\mathbf{2 d}$ and 2e. The acetalization step was much slower than the hydroformylation as relative amounts of acetals increased with the reaction time. However, we could not find the reaction conditions to convert completely the aldehydes to the acetals. At longer reaction times the content of acetals did not increase suggesting a thermodynamic equilibrium, whereas at higher temperature the combined selectivity for the hydroformylation products became to decrease due to the formation of numerous unidentified compounds. Thus, the hydroformylation of $\beta$-citronellene in ethanol solutions can result, depending on the reaction temperature, either almost exclusively in the aldehyde products or in a mixture of aldehydes and acetals with different organoleptic properties.

It has been previously reported that $\mathrm{RhCl}_{3}$ in the combination with $\mathrm{P}(\mathrm{OPh})_{3}$ is an efficient catalyst for the hydroformylation-acetalization of alkenes without the addition of acid co-catalysts [41,42]. Intermediate rhodium-chloro-phosphite complexes having Lewis acidity were suggested as active species

Table 6

Hydroformylation of $\beta$-citronellene (2a) in ethanol. ${ }^{\mathrm{a}}$

\begin{tabular}{|c|c|c|c|c|c|c|c|c|c|c|}
\hline \multirow[t]{3}{*}{ Run } & \multirow[t]{3}{*}{ Ligand } & \multirow[t]{3}{*}{$\mathrm{P} / \mathrm{Rh}$} & \multirow[t]{3}{*}{$T\left({ }^{\circ} \mathrm{C}\right)$} & \multirow[t]{3}{*}{ Time $(\mathrm{h})$} & \multirow[t]{3}{*}{$\operatorname{TOF}\left(\mathrm{h}^{-1}\right)$} & \multicolumn{5}{|c|}{ Selectivity (\%) } \\
\hline & & & & & & \multicolumn{2}{|c|}{ Aldehydes } & \multicolumn{2}{|c|}{ Acetals } & \multirow[t]{2}{*}{ Aldehydes/acetals } \\
\hline & & & & & & $\mathbf{2 b}$ & 2c & 2d & $2 e$ & \\
\hline $1^{\mathrm{b}}$ & None & & 40 & 24 & 18 & 70 & 25 & 5 & - & $95 / 5$ \\
\hline 2 & $\mathrm{PPh}_{3}$ & 5 & 40 & 24 & 32 & 63 & 12 & 24 & 1 & $75 / 25$ \\
\hline 3 & $\mathrm{PPh}_{3}$ & 10 & 40 & 24 & 29 & 62 & 11 & 24 & 2 & $73 / 26$ \\
\hline 4 & $\mathrm{P}\left(\mathrm{O}-\mathrm{O}-{ }^{-}{ }^{\mathrm{t}} \mathrm{BuPh}\right)_{3}$ & 5 & 40 & 1.00 & 540 & 66 & 28 & 6 & - & $94 / 6$ \\
\hline 5 & $\mathrm{P}\left(\mathrm{O}-\mathrm{o}-{ }^{\mathrm{t}} \mathrm{BuPh}\right)_{3}$ & 10 & 40 & 1.25 & 550 & 63 & 27 & 8 & 1 & $90 / 9$ \\
\hline 6 & $\mathrm{P}\left(\mathrm{O}-\mathrm{o}-{ }^{\mathrm{t}} \mathrm{BuPh}\right)_{3}$ & 20 & 40 & 1.25 & 360 & 61 & 22 & 15 & 2 & $83 / 17$ \\
\hline \multirow[t]{2}{*}{$7^{c}$} & $\mathrm{P}\left(\mathrm{O}-\mathrm{O}-{ }^{\mathrm{t}} \mathrm{BuPh}\right)_{3}$ & 5 & 60 & 0.25 & 1600 & 73 & 23 & 4 & & $96 / 4$ \\
\hline & & & & 4.00 & & 48 & 20 & 24 & 2 & $68 / 26$ \\
\hline \multirow[t]{2}{*}{$8^{c}$} & $\mathrm{P}\left(\mathrm{O}-\mathrm{o}-{ }^{\mathrm{t}} \mathrm{BuPh}\right)_{3}$ & 5 & 80 & 0.25 & 1600 & 39 & 19 & 39 & 3 & $58 / 42$ \\
\hline & & & & 1.00 & & 26 & 15 & 50 & 6 & $41 / 56$ \\
\hline
\end{tabular}

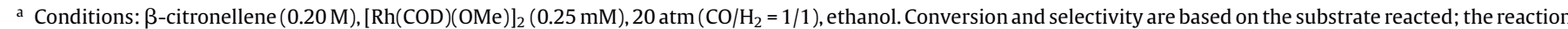
time is given for nearly complete conversions. TOF - initial turnover frequency (mol of the converted substrate per mol of Rh per hour).

b $55 \%$ conversion for $24 \mathrm{~h}$.

c Average TOF is given as the reaction was too fast. 
in the conversion of alkene into aldehyde followed by acetalization. We have tested the $\mathrm{RhCl}_{3} / \mathrm{P}\left(\mathrm{O}-\mathrm{O}_{-}{ }^{\mathrm{t}} \mathrm{BuPh}\right)_{3}$ system in the hydroformylation of linalool and $\beta$-citronellene in ethanol solutions. Both reactions gave mainly etherification or acetalization products (ethyl ether 1d from linalool and acetals 2d and 2 e from $\beta$-citronellene); however, substrate conversions occurred much slower than with $\mathrm{Rh}(\mathrm{COD})(\mathrm{OMe})]_{2}$ as the catalyst precursor. Under the same conditions, when a complete conversion of linalool (Table 5, run 7) and $\beta$-citronellene (Table 6, run 8) with $\mathrm{Rh}(\mathrm{COD})(\mathrm{OMe})]_{2}$ occurred for 2 and $0.25 \mathrm{~h}$, respectively; the reactions with $\mathrm{RhCl}_{3}$ required much longer reaction times (22 and $2 \mathrm{~h}$, respectively).

\section{Conclusions}

The study of the rhodium-catalyzed hydroformylation of linalool and $\beta$-citronellene in toluene and ethanol solutions revealed a remarkable effect of the solvent and the nature of the auxiliary phosphorous ligand on the substrate reactivity and product distribution. The reactions occurs approximately two times faster in ethanol than in toluene and up to twenty times faster in the $\mathrm{Rh} / \mathrm{P}\left(\mathrm{O}-\mathrm{O}_{-}{ }^{\mathrm{t}} \mathrm{BuPh}\right)_{3}$ system as compared to the system with $\mathrm{PPh}_{3}$. Differently from $\beta$-citronellene, linalool is very resistant to hydroformylation in the absence of P ligands, probably, due to the binding through both the double-bond and the hydroxyl group to form stable chelates with rhodium. The appropriate choice of the reaction variables allows for the stereochemistry control in tetrahydrofuran derivatives 1c and 1d, which are formed nearly quantitatively in toluene and ethanol solutions, respectively. The hydroformylation of $\beta$-citronellene in ethanol solutions can result, depending on the reaction temperature, either almost exclusively in aldehyde products or in a mixture of aldehydes and acetals with different organoleptic properties. Several fragrance compounds can be obtained in high yields through a simple one-pot procedure starting from the substrates easily available from natural bio-renewable resources. It is important to point out that the reactions can be performed in ethanol, an environmentally friendly solvent, in the absence of additional acid co-catalysts and, due to the high reactivity of the substrates induced by bulky phosphite ligand, under mild reaction conditions.

\section{Acknowledgment}

We acknowledge CNPq, FAPEMIG, and INCT-Catálise (Brazil) for the financial support.

\section{References}

[1] E. Breitmaier, Terpenes. Flavors, Fragrances, Pharmaca, Pheromones, WilleyVCH, Weinheim, 2006.
[2] A. Behr, L. Johnen, ChemSusChem 2 (2009) 1072-1095.

[3] H. Mimoun, Chimia 50 (1996) 620-625.

[4] K.A.D. Swift, Top. Catal. 27 (2004) 143-155.

[5] M.J. da Silva, J.A. Gonçalves, O.W. Howarth, R.B. Alves, E.V. Gusevskaya, J. Organomet. Chem. 689 (2004) 302-308.

[6] P.A. Robles-Dutenhefner, K.A. da Silva Rocha, E.M.B. Sousa, E.V. Gusevskaya, J. Catal. 265 (2009) 72-79.

[7] V.V. Costa, M.J. Jacinto, L.M. Rossi, R. Landers, E.V. Gusevskaya, J. Catal. 282 (2011) 209-214.

[8] C.G. Vieira, M.C. de Freitas, E.N. dos Santos, E.V. Gusevskaya, ChemCatChem 4 (2012) 795-801.

[9] C.G. Vieira, J.G. da Silva, C.A.A. Penna, E.N. dos Santos, E.V. Gusevskaya, Appl. Catal. A 380 (2010) 125-132.

[10] P.W.N.M. van Leeuwen, C. Claver (Eds.), Rhodium Catalyzed Hydroformylation, Kluwer Academic Publisher, Dordrecht, 2000.

[11] A.J. Chalk, in: W.M. Lawrence, B.D. Mookherjee, B.J. Willis (Eds.), Flavors and Fragrances: A World Perspective. Proceedings of the 10th International Congress of Essential Oils, Fragrances and Flavors, Washington, DC, USA, 1986, pp. 867-882.

[12] Ciprés, Ph. Kalck, D.-C. Park, F. Serein-Spirau, J. Mol. Catal. 66 (1991) 399-407.

[13] I.S. Sirol, Ph. Kalck, New J. Chem. 21 (1997) 1129-1137.

[14] H.J.V. Barros, J.G. da Silva, C.C. Guimarães, E.N. dos Santos, E.V. Gusevskaya, Organometallics 27 (2008) 4523-4531.

[15] K. Soulantica, S. Sirol, S. Koinis, G. Pneumatikakis, Ph. Kalck, J. Organomet. Chem. 498 (1995) C10.

[16] L. Kollár, G. Bódi, Chirality 1 (1995) 121-127.

[17] C.M. Foca, E.N. dos Santos, E.V. Gusevskaya, J. Mol. Catal. A 185 (2002) 17-23.

[18] F. Azzaroni, P. Biscarini, S. Bordoni, G. Longoni, E. Venturini, J. Organomet. Chem. 508 (1996) 59-67.

[19] C.M. Foca, H.J.V. Barros, E.N. dos Santos, E.V. Gusevskaya, J.C. Bayon, New J. Chem. 27 (2003) 533-539.

[20] H.J.V. Barros, E.V. Gusevskaya, E.N. dos Santos, J. Organomet. Chem. 671 (2003) $150-157$.

[21] G.A. Korneeva, M.M. Minkovskii, N.A. Novikov, I.S. Istochnikova, M.M. Potarin, E.V. Slivinskii, RU 2058309, 1996.

[22] M. Benaissa, U.J. Jáuregui-Haza, I. Nikov, A.M. Wilhelm, H. Delmas, Catal. Today 79-80 (2003) 419-425.

[23] J.G. da Silva, H.J.V. Barros, E.N. dos Santos, E.V. Gusevskaya, Appl. Catal. A 309 (2006) 169-176.

[24] M.T. Reetz, S.R. Waldvogel, R. Goddard, Heterocycles 52 (2000) 935-938.

[25] H. Siegel, W. Himmele, Angew. Chem. Int. Ed. 19 (1980) 178-183.

[26] V.A. Semikolenov, I.I. Ilyna, I.L. Simakova, Appl. Catal. A 211 (2001) 91-107.

[27] A.M. Trzeciak, E. Wolszczak, J.J. Ziólkowski, New J. Chem. 20 (1996) 365-370.

[28] K. Nozaki, W. Li, T. Horiochi, H. Takaya, Tetrahedron Lett. 38 (1997) 4611-4614.

[29] S. Sirol, Ph. Kalck, New J. Chem. 21 (1997) 1129-1137.

[30] J.T. Sullivan, J. Sadula, B.E. Hanson, R.J. Rosso, J. Mol. Catal. A 214 (2004) 213-218

[31] A. Stolle, B. Ondruschka, W. Bonrath, T. Netscher, M. Findeisen, M.M. Hoffmann, Chem. Eur. J. 14 (2008) 6805-6814.

[32] A. Stolle, B. Ondruschka, W. Bonrath, Eur. J. Org. Chem. (2007) 2310-2317.

[33] D.S. Meloa, S.S. Pereira-Júnior, E.N. dos Santos, Appl. Catal. A 411-412 (2012) $70-76$.

[34] K.C.B. Oliveira, A.G. Santos, E.N. dos Santos, Appl. Catal. A 445-446 (2012) 204-208.

[35] M.C. de Freitas, C.G. Vieira, E.N. dos Santos, E.V. Gusevskaya, ChemCatChem (2013), http://dx.doi.org/10.1002/cctc.201200948.

[36] R. Uson, L.A. Oro, J.A. Cabeza, Inorg. Synth. 23 (1985) 126-127.

[37] P.W.N.M. van Leeuwen, C.F. Roobeek, J. Organomet. Chem. 258 (1983) 343-350.

[38] A. van Rooy, E.N. Orij, P.C.J. Kamer, P.W.N.M. van Leeuwen, Organometallics 14 (1995) 34-43.

[39] A.A. Dabbawala, H.C. Bajaj, G.V.S. Rao, S.H.R. Abdi, Appl. Catal. A 419-420 (2012) $185-193$.

[40] H. Tricas, O. Diebolt, P.W.N.M. van Leeuwen, J. Catal. 298 (2013) 198-205.

[41] B. El Ali, J. Tijani, M. Fettouhi, J. Mol. Catal. A 230 (2005) 9-16.

[42] B. El Ali, J. Tijani, M. Fettouhi, Appl. Catal. A 303 (2006) 213-220. 